\title{
Rheological properties of oil-in-water emulsions prepared with oil and protein isolates from sesame (Sesamum Indicum)
}

\author{
David Ramirez BREWER ${ }^{1}$, José Maria FRANCO², Luis Alberto GARCIA-ZAPATEIRO ${ }^{1,2 *}$
}

\begin{abstract}
In this study, food emulsions of oil in water from sesame (Sesamum indicum) protein isolates and their oil were formulated and standardised. The effect of the concentrations of sesame (Sesamum indicum) protein isolates and base oil and the speed of the emulsification process for the food emulsion stability was studied. The protein isolates were achieved from the defatted sesame flour (DSF), obtaining a percentage of $80 \% \pm 0.05 \%$ of protein. Emulsions were formulated through a factorial design $2^{3}$. The rheological behaviour of sesame (Sesamum indicum) protein isolates-stabilised emulsions and microstructural composition were investigated. Stable emulsions with suitable rheological properties and microstructure were formulated at a concentration of $10 \%$ sesame oil and different concentrations of protein isolates, between $1.5 \%$ and $2.5 \%$, with the best droplet distribution characteristics being shown for the $2.5 \%$ sesame protein isolates. The emulsions showed a non-Newtonian fluid behaviour, adjusting the Sisko model.
\end{abstract}

Keywords: dispersions; non-Newtonian fluid; Sisko model; microstructure.

Practical Application: Food emulsion from sesame are an alternative of new products.

\section{Introduction}

Sesame (Sesamum indicum) seed has an oil content of between $57 \%$ and $63 \%$; as a result, it has become one of the main sources of edible oil. It is also a good source of protein, yielding between $23 \%$ and $25 \%$ protein. (Tunde-Akintunde et al., 2012). This oil is important source of edible oil due to its high essential fatty acids, oleic (43\%), linoleic (35\%), palmitic (11\%) and stearic (7\%) acids, which together comprised about $96 \%$ of the total fatty acids (Elleuch et al., 2007). Sesame oil contains sesamin and sesaminol lignans in the non-glycerol fraction, which plays an important role in the oxidative stability and anti-oxidative activity, it can be used to cook meals of high quality (Saydut et al., 2008)

One of the principal characteristics of this protein is its high methionine and tryptophan content. Sesame proteins, while contributing to the nutritional value of foods, can also be used as additives; their interesting functional properties reflect their physico-chemical characteristics, composition and structure (Wagner \& Gueguen, 1999; Autran et al., 2001; Bradley, 2002; Escamilla-Silva et al., 2003).

An emulsion consists of two immiscible liquids (usually oil and water), with one of the liquids dispersed as small spherical droplets in the other. In most foods, the diameters of the droplets are usually somewhere between 0.1 and $100 \mu \mathrm{m}$ (Dickinson \& Stainsby, 1982; Dickinson \& Rodriguez, 1999; Walstra, 1996a, b). There are two basic forms of emulsion. The first is the oil-in-water $(\mathrm{O} / \mathrm{W})$ emulsion, in which oil droplets are dispersed and encapsulated within the water column, while the second is the water-in-oil (W/O) emulsion, in which droplets of water are dispersed and encapsulated within the oil (Gonglun \& Tao, 2004).

The stability of a food emulsion is the most important to consider in relation to their industrial applications factor, and depends on the size distribution of the dispersed phase droplets, the rheology of the continuous phase and the interactions between particles of the dispersed phase (Melik \& Fogler, 1998). Most of the $\mathrm{O} / \mathrm{W}$ food emulsion oils are stabilised by macromolecular emulsifiers (biopolymers).

Functional properties of protein are important in food processing, and food formulation. Some of these properties are solubility, water and oil holding capacity, foaming capacity and stability, gelation, bulk density and viscosity. The importance of these properties varies with the type of food products in which the protein isolate is to be used (Onsaard, 2012).

Thus, proteins extracted from a variety of natural sources can be used as emulsifiers in foods because of their ability to facilitate the formation, improve the stability, and produce desirable physicochemical properties in oil-in-water $(\mathrm{O} / \mathrm{W})$ emulsions, e.g. soy, whey, casein, fish, meat and plant proteins (Dickinson, 2003; McClements, 2004). Owing to the coexistence of hydrophilic and hydrophobic parts in their structure, proteins show amphiphilic nature which is essential for having emulsifying property. They reduce the oil-water interfacial tension and thus facilitate formation of emulsion. They also stabilize the oil droplets 
against coalescence or flocculation by spatial and electrostatic repulsion mechanisms (Calero et al., 2013).

Khalid et al. (2003) reported that the functional properties of the protein sesame properties, such as emulsifying and foaming properties were higher than other proteins. Moreover, its water holding, and fat-holding capacities, bulk density and other properties are good. Therefore, it can be used in food formulation systems. Onsaard et al. (2010) reported that solubility and emulsifying activity of the sesame protein concentrates were higher than those of soy protein isolate, while emulsion stability index, foaming properties, water holding capacity and fat absorption capacity of sesame protein concentrates were lower than those of soy protein isolate. Therefore, these proteins may be used as a food ingredient to substitute for soy protein isolate, where solubility and emulsifying properties are needed.

The aim of the present work was to prepare O/W emulsion under different conditions using oil and protein isolates from sesame (Sesamum indicum) and evaluate the rheological properties of the emulsions.

\section{Materials and methods}

\subsection{Material}

Sesame (Sesamum indicum) seed was obtained in a township of Bolivar department. The seed was stored at optimal conditions and transported to pilot plant technology of cereals and oleaginous of University of Cartagena. Sodium hydroxide, sodium chloride $(\mathrm{NaCl})$ and hydrochloric acid $(\mathrm{HCl})$ Sigma - Aldrich (St. Louis. $\mathrm{MO}$, USA) were used as reagents to obtain protein isolates.

\subsection{Extraction procedure and physicochemical characterization of sesame oil}

Sesame (Sesamum indicum) oil was extracted for the mechanical pressing method. The analysis of sesame oil was realised in triplicate determining density, and the index of refraction, using the procedures describe for the Association of Official Analytical Chemist (1998). The determination of fatty acid profile was performed by gas chromatography using an Agilent 4890D gas chromatograph.

\subsection{Isolation protocol and characterization of sesame (Sesamum indicum) protein isolates}

Sesame (Sesamum indicum) protein isolate (SPI) was prepared according to the procedure of Onsaard et al. (2010), with some modifications. Defatted sesame flour (DSF) was suspended in different solutions of $\mathrm{NaCl}$ at $1.0 \mathrm{M}, 2.0 \mathrm{M}, 3.0 \mathrm{M}, 4.0 \mathrm{M}$ and $5.0 \mathrm{M}$ at a ratio of $1: 10(\mathrm{w} / \mathrm{v})$ at $\mathrm{pH}$ 7, to evaluate their influence on amount of protein isolated. The suspended sesame flour was stirred with a magnetic stirrer for $1 \mathrm{~h}$ and then centrifuged at $3800 \mathrm{rpm}$ for $15 \mathrm{~min}$ to separate solution phases. The soluble phases were adjusted to $\mathrm{pH} 4.5 \%$ or $10 \% \mathrm{HCl}$ which led the precipitation of protein. The suspensions were centrifuged at $3800 \mathrm{rpm}$ for $15 \mathrm{~min}$. The precipitates were washed with excess water and centrifuged. The protein content present in the DSF and isolates was determined by the Kjeldahl method, proposed in the Association of Official Analytical Chemist (1998).

\subsection{Preparation of emulsions}

Oil-in-water emulsions were prepared with oil and protein isolated from sesame (Sesamum indicum) and deionized water. A complete factorial design $2^{3}$ was used to analyse the influences of speed of emulsification (8000 and $11400 \mathrm{rpm}$ ), isolated protein $(1.5 \%, 2.5 \%)$ and oil $(10 \%, 20 \%)$ concentrations on the stability of emulsions, shown in Table 1.

The protein isolates were dispersed in distilled water, and the $\mathrm{pH}$ was adjusted to 11 taking into account the results reported by Onsaard et al. (2010), what showed that at $\mathrm{pH}$ higher than 9 , the solubility of the protein increased. The solutions were homogenised for $2 \mathrm{~min}$ at $8000 \mathrm{rpm}$. Then emulsions were prepared by adding sesame oil to a solution of water-protein sesame (Sesamum indicum) to $\mathrm{pH} 11 \pm 0.5$ using an homogenizar, rotor stator system, Ultra Turrax T25, equipped with a dispersion element S25N-10G ST, working to 8000 to $11600 \mathrm{rpm}$ for $10 \mathrm{~min}$ for all emulsions. Finally, emulsions were stored at $4{ }^{\circ} \mathrm{C}$ and placed at $25^{\circ} \mathrm{C}$ for 30 minutes before taking any mesasurements.

\subsection{Rheological and Microstructural Characterization}

Tests were performed of viscous emulsions made with a Brookfield DV-E viscometer strain (Brookfield Engineering Laboratories, Massachusetts, USA). Readings between 0 and 100 scale units were taken (spindle $n^{\circ} 3$ ) at rotational speeds between 5 to $100 \mathrm{rpm}$. Scale values were read after 90 seconds under shear. For each emulsion sample, the measurements were an average of three replicates. The temperature $\left(25^{\circ} \mathrm{C}\right)$ of the emulsion was maintained during the measurements. The microstructure of emulsion was measured using a standard optical microscope Leica D500 Germany. Photographs were taken from typical fields to compare the changed ability of standardised emulsion.

\section{Results and discussions}

\subsection{Physicochemical characterisation and obtaining sesame oil from seed}

Sesame oil was obtained by the method of mechanical pressing sesame (Sesamum indicum) seed, recovering 63.75\% of the total oil present in the seed.

The physicochemical composition of sesame oil is shown in Table 2; these results are compared to the standards established by Colombian legislation, in its resolution 0126 of 1984, finding the values obtained within the range established by Colombian

Table 1. Experimental design of emulsion.

\begin{tabular}{cccc}
\hline $\begin{array}{c}\text { Sample } \\
\text { Codes }\end{array}$ & $\begin{array}{c}\text { Protein } \\
\text { concentration } \\
(\% \text { w/w })\end{array}$ & $\begin{array}{c}\text { Oil } \\
\text { Concentration } \\
(\% \text { w/w })\end{array}$ & $\begin{array}{c}\text { Speed } \\
\text { Homogenisation } \\
(\mathbf{r p m})\end{array}$ \\
\hline Sample 1 & 1.5 & 20 & 11400 \\
Sample 2 & 2.5 & 10 & 11400 \\
Sample 3 & 1.5 & 20 & 8000 \\
Sample 4 & 2.5 & 10 & 8000 \\
Sample 5 & 2.5 & 20 & 8000 \\
Sample 6 & 2.5 & 20 & 11400 \\
Sample 7 & 1.5 & 10 & 11400 \\
Sample 8 & 1.5 & 10 & 8000 \\
\hline
\end{tabular}


standards, which were used to ensure the optimum quality oil for processing.

Table 3 shows the result of the fatty acid profile of sesame oil. These results are compared with the set of food standards codex, and were found to be within the established range.

\subsection{Production and characterisation of sesame protein isolates}

The results of the extraction of protein and contents in the DSF are shown in Table 4 and the relation of protein content in relation to concentration of $\mathrm{NaCl}$.

A proportional relation between protein and concentration of $\mathrm{NaCl}$ were found, due an increase of percentage of protein with increasing $\mathrm{NaCl}$ concentration, the highest protein recovery was found at $4.0 \mathrm{M} \mathrm{NaCl}(80.43 \pm 0.01)$, while the lowest protein recovery was found at $1 \mathrm{M} \mathrm{NaCl}(54.69 \pm 0.02)$. Beyond $5 \mathrm{M} \mathrm{NaCl}$ a decrease (salting-out) of protein content was obtain.

This behaviour due to the salt ions interact with oppositely charged groups, which in turn decreases electrostatic attraction between protein molecules and causes the proteins to become more solvent (Vojdani, 1996). This salting-out effect results from the competition between the protein and the salt ions for the water molecules necessary for their respective solvency. At high salt concentrations, there are not enough water molecules available for protein solvency, since the majority of the water molecules are strongly bound to the salts. Thus, protein-protein interactions become more powerful than protein-water interactions. This behaviour is similar to that reported by Onsaard et al. (2010) and Achouri et al. (2012) who reported that increasing the $\mathrm{NaCl}$ concentration increased the yield of the protein.

\subsection{Formulation of emulsions.}

The emulsions were prepared using different concentrations of oil, protein isolates from sesame (Sesamun indicum) and different levels of emulsification velocity, obtaining eight formulations, shown in Table 1. The emulsions 2, 4 and 8 obtained after completed homogenization process were stable and keeping its physical characteristic until rheological and microstructural analysis. The stabilized sample, containing the same concentration of $10 \%$ oil sesame. The samples 1, 3, 5, 6 and 7 destabilize through a creaming phenomenon which is detected by aqueous phase separation at the bottom of the storage flask, creaming is the process by which buoyant emulsion droplets tend to rise to the top of a container. It is the same process as sedimentation, but in the opposite direction. (Robins, 2000; Dickinson, 2003) As shown in Table 1, oil concentration decisively influences stability against creaming.

\subsection{Rheological and microstructural characterisation}

Rheological and microstructural characterisation were carried out on stable emulsions at $25^{\circ} \mathrm{C}$. Viscosity, concentration of protein and homogenisation rates were studied. Figure 1 show that the apparent viscosity decreased with increasing shear rate applied for all samples, this behavior is defined as a characteristic of a Non-Newtonian fluid type Shear-thinning (Macosko, 1994). The viscosity decreased as the shear rate increased for all samples after a sharp reduction, the viscosity change was smoothened at high shear rates. Shear-thinning behavior in the dispersions with proteins is due to the gradual orientation of the molecules in the direction of flow in order to reduce the frictional resistance and deformation of proteins by hydration in the direction of flow. Hydrogen bonds and

Table 2. Physicochemical properties of Sesame (Sesamum indicum) oil.

\begin{tabular}{lcc}
\hline Density $\left(\mathrm{g} / \mathrm{cm}^{3}\right)$ & $0.935^{\mathrm{a}}$ & $0.912-0.930^{\mathrm{b}}$ \\
Refractive index (Grade Refraction) & $1.441^{\mathrm{a}}$ & $1.471-1.474$ \\
\hline${ }^{\text {a}}$ Results obtained Laboratories of the University of Cartagena. ${ }^{\mathrm{b}}$ Invima Standard Values. \\
19840126 resolution.
\end{tabular}

Table 3. Fatty acid composition of sesame (Sesamum indicum) oil.

\begin{tabular}{ccc}
\hline \multicolumn{3}{c}{ Fatty Acid Composition $(\% w / w)$} \\
\hline Fatty Acid & Sesame oil $^{\mathrm{a}}$ & Sesame oil $^{\mathrm{b}}$ \\
\hline Acid Palmitic & 9.24 & $7.9-12.0$ \\
Acid Linoleic & 49.38 & $36.9-47.9$ \\
Acid Oleic & 34.58 & $34.4-45.5$ \\
Acid Stearic & 5.95 & $4.5-6.7$ \\
\hline
\end{tabular}

aProfile of fatty acids. Laboratories University of Cartagena. ${ }^{\text {SStandard } 210-1999 \text { CODEX }}$ Stan for oils.

Table 4. Chemical composition of sesame protein isolates and defatted sesame flour (DSF).

\begin{tabular}{cccc}
\hline Sample & Protein (\%) & Moisture (\%) & Fat (\%) \\
\hline $\begin{array}{c}\text { Defatted sesame } \\
\text { flour (DSF) }\end{array}$ & $55 \pm 0.05$ & -- & -- \\
SPI at $1 \mathrm{M}$ & $54.69 \pm 0.02$ & -- & -- \\
SPI at $2 \mathrm{M}$ & $68.66 \pm 0.12$ & -- & -- \\
SPI at 3M & $77.41 \pm 0.03$ & -- & -- \\
SPI at 4M & $80.43 \pm 0.01$ & 7.5 & -- \\
SPI at 4M & $75.64 \pm 0.02$ & -- & -- \\
SPI-Salt & 75.49 & 7.17 & 0.51 \\
\hline
\end{tabular}

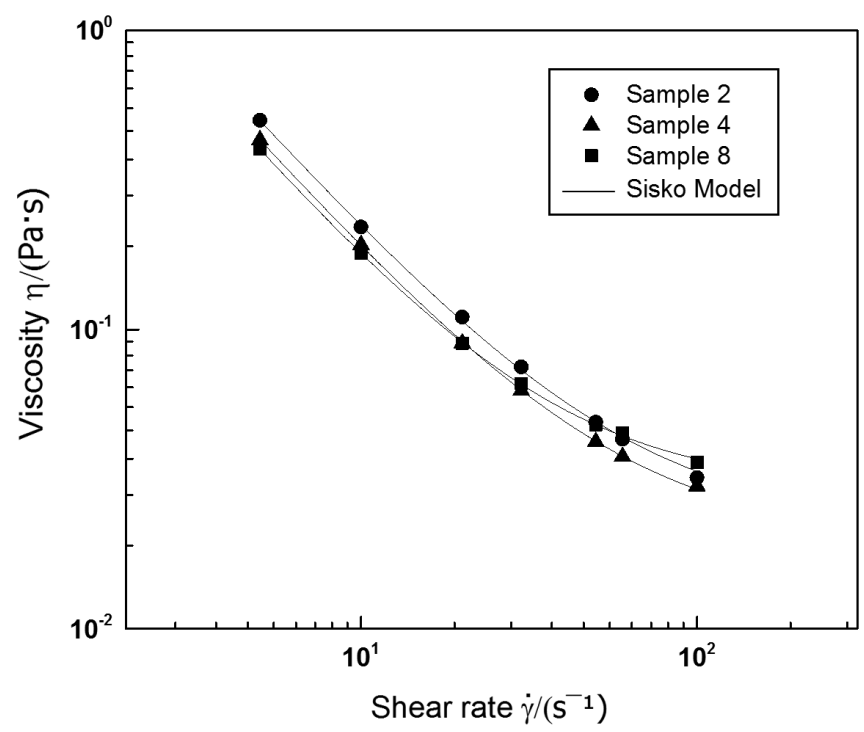

Figure 1. Viscosity-rate of shear curves for $\mathrm{o} / \mathrm{w}$ emulsion at room temperature $\left(25^{\circ} \mathrm{C}\right)$. 
some weak bonds are broken, which leads to the dissociation of aggregates of protein networks (Fennema, 2000). As the shear rate increased, the particle-particle interaction was disturbed and eventually disrupted, which resulted in a reduction in flocs size and resulted in a decrease in viscosity. At higher shear rates, the viscosity reached a constant value because all flocs and large particles were completely disrupted. Therefore, only individual and small particles remained in the system (McClements, 1999).

The shear-thinning behaviour of dispersions with proteins is explained by the possibility that the protein molecules, which are large, may direct their major axis with respect to the direction of flow of the solution. The disaggregation of multimeric proteins contributes to this behaviour. After the cessation of shear flow or stop, proteins require a relaxation period to lose the orientation they had obtained, and to regain their original state (Badui, 2006). Thus, the Sisko equation was used to model the behaviour of the Emulsion 1:

$\eta=\eta_{\infty}+K_{s} \gamma^{n-1}$

Parameters $K_{s}$ and $n$ are consistency and flow indices, respectively, whereas $\eta_{\infty}$ is the asymptotic viscosity value at high shear rates. The parameter $K_{s}$ can be considered an index of the material "consistency", whereas $n$ is always positive and lower than one, and can be considered a measure of the structural breakdown rate. From a physical point of view, the lower the $n$ value, the higher the curve slope, meaning that a sharper decrease in viscosity occurs when shear rate increases (greater tendency to in-flow destructuration) (Lupi et al., 2011).

Sisko model parameters were computed by fitting experimental data, and good agreement was observed in Table 5, where good fits were obtained with a high correlation coefficient $\left(R^{2}>0.9997\right)$. At very low rates of deformations, the viscosity is not constant and is called apparent viscosity; at some points, this begins to decrease, and a curve region generally enters a logarithmic graph, indicating the Sisko model behaviour. Analogous results were obtained in oil in water emulsions stabilized with fish protein were reported by Quintana et al. (2015), where the tendency to reach the infinite-shear rate Newtonian viscosity was observed. For samples 4 and 8, where the speed of homogenisation and protein concentration were increased but the formulation remained constant, an increase in consistency index and a decreased rate of flow were observed. Moreover, an increase in the index of consistency was observed when comparing sample
2 with other samples. Similar results were reported by Lupi et al. (2011). The flow index values, $n$, slightly decreased, providing evidence of a different dependence of the emulsion network on shear flow conditions.

Figure 2 shows the distribution of particle-stabilised emulsions. The microstructure had no qualitative differences in droplet sizes. Partal et al. (1997) and Guerrero et al. (1998) reported that the increase in rheological functions of emulsions with oil concentration is accompanied by a decrease in mean droplet diameter. The microstructure showed significant differences in distribution and droplet size according to the protein concentration and velocity of emulsification. Polydispersed emulsions were observed with a droplet surrounded by a continuous aqueous phase. As the protein concentration increased, a better size distribution of droplets was observed, due to the fact that proteins play an important role in the stability of emulsions. It was evident that increasing the protein concentration and increasing the shear rate distribution improved the droplet size as sample b (emulsion at $2.5 \%$ protein and $11400 \mathrm{rpm}$ ), due to the role of the proteins as emulsifiers.

The influence of mechanical processing variables on vegetable protein-stabilised emulsions is mainly affected by droplet size and distribution (Franco et al., 1998). Many proteins are surface-active molecules that can be used as emulsifiers because of their ability to facilitate the formation, improve the stability and produce desirable physicochemical properties in oil-in-water emulsions (Norde 2003; Quintana et al., 2015). Proteins adsorb to the surfaces of freshly formed oil droplets created by the homogenisation of oil-water-protein mixtures, where they facilitate further droplet disruption by lowering the interfacial tension and retard droplet coalescence by forming protective membranes around the droplets (Walstra, 2003). Figure $2 \mathrm{~b}$ showed better characteristics, with a highest viscosity

Table 5. Sisko model parameters for different sample codes at $25^{\circ} \mathrm{C}$.

\begin{tabular}{ccccc}
\hline Sample codes & $\boldsymbol{\eta}_{\infty}(\boldsymbol{P a} . \boldsymbol{s})^{\boldsymbol{a}}$ & $\boldsymbol{k}_{\boldsymbol{s}}\left(\boldsymbol{P a} . \boldsymbol{s}^{n}\right)^{\boldsymbol{b}}$ & $\boldsymbol{\eta}_{\boldsymbol{s}}(\boldsymbol{P a} . \boldsymbol{s})^{\boldsymbol{c}}$ & $\boldsymbol{R}^{\mathbf{2}}$ \\
\hline Sample 2 & 0.023 & 3.557 & 0.248 & 0.9997 \\
Sample 4 & 0.020 & 3.127 & 0.262 & 0.9999 \\
Sample 8 & 0.029 & 2.999 & 0.299 & 0.9999 \\
\hline
\end{tabular}

astandard deviation for $\eta$ is always lower than $10^{-4}$. ${ }^{\mathrm{b}}$ standard deviation for $K$ is always lower than $10^{-2}$. ${ }^{\mathrm{c}} \mathrm{standard}$ deviation for $\eta_{s}$ is always lower than $10^{-3}$.
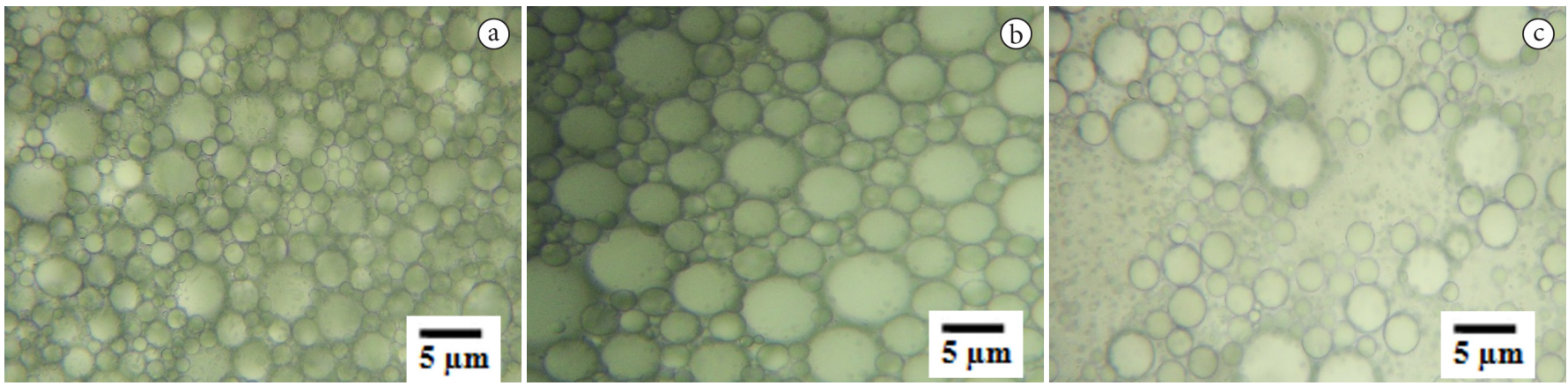

Figure 2. Micrograph of homogenised emulsions at $8000 \mathrm{rpm}(\mathrm{a}, \mathrm{c})$ and $11400 \mathrm{rpm}$ (b) at different concentration of protein isolates $1.5 \%$ wt (a) and $2.5 \mathrm{wt} \%(\mathrm{~b}, \mathrm{c})$. 
that led to high resistance of the fluid against the flow, a similar droplet size and better distribution representing better stability

\section{Conclusions}

The composition of the sesame oil was within the parameters established by the standard. The use of this oil in the formulation of food products is an added-value due to its chemical composition, which is rich in unsaturated fatty acids. The defatted sesame flour (DSF) can be seen as a good source of protein, which was obtained at a protein isolate concentration of $80.43 \% \pm 0.01 \%$. The protein isolate was used in the formulation and standardisation of oil in water food emulsions. Food emulsions (samples 2, 4 and 8) were standardised oil in water with a protein concentration of $1.5 \%$ to $2.5 \%$, with a concentration of the oil phase of $10 \%$

The stabilised emulsions exhibit a non-Newtonian fluid behaviour, adjusting well to the Sisko model. At higher homogenisation speed values, a decrease of flow index and consistency index increase was observed. The emulsions in study showed similar rheological properties according to Sisko model parameters, which is evident in the distribution and droplet size of the emulsions. The qualitative analysis of the microstructure showed similar droplet size distribution have an influence on the viscosity of emulsions. Sample 4 shows better characteristics, with a highest viscosity that led to high resistance of the fluid against the flow, a similar droplet size and better distribution representing better stability.

Finally, the results of this project promote the use of raw materials with regional interest for the development of new products; for example, sesame has a chemical composition, including oil and protein, which is of very good quality and has excellent properties for the formulation and development of food products.

\section{Acknowledgements}

This work is part of a research project "Training Project of Young Scientists of COLCIENCIAS" (566 2012) sponsored by COLCIENCIAS (Colombia). The authors gratefully acknowledge its financial support.

\section{References}

Achouri, A., Nail, V., \& Boye, J. I. (2012). Sesame protein isolate: fractionation, secondary structure and functional properties. Food Research International, 46(1), 360-369. http://dx.doi.org/10.1016/j. foodres.2012.01.001.

Association of Official Analysis Chemists - AOAC. (1998). International official methods of analysis. Washington, DC: AOAC.

Autran, J. C., Halford, N. G., \& Shewry, P. R. (2001). The biochemistry and molecular biology of seed storage proteins. In P. D. Lea \& J. F. Morot-Gaudry (Eds.), The assimilation of nitrogen by plants (pp. 295-341). Berlin: Springer-Verlag.

Badui, D. S. (2006). Food chemistry (4th ed.). Mexico: Pearson Education.

Bradley, M. J. (2002). Food, industrial, nutraceutical, and pharmaceutical uses of sesame genetic resources. In J. Janick \& A. Whipkey (Eds.), Trends in new crops and new uses (pp. 153-156). Alexandria: ASHS Press.
Calero, N., Munoz, J., Cox, P. W., Heuer, A., \& Guerrero, A. (2013). Influence of chitosan concentration on the stability, microstructure and rheological properties of $\mathrm{O} / \mathrm{W}$ emulsions formulated with high-oleic sunflower oil and potato protein. Food Hydrocolloids, 30(1), 152-162. http://dx.doi.org/10.1016/j.foodhyd.2012.05.004.

Dickinson, E. (2003). Hydrocolloids at interfaces and the influence on the properties of dispersed systems. Food Hydrocolloids, 17(1), 25-39. http://dx.doi.org/10.1016/S0268-005X(01)00120-5.

Dickinson, E., \& Rodriguez, J. M. (1999). Advances in food emulsion \& foams. London: Elsevier.

Dickinson, E., \& Stainsby, G. J. (1982). Colloids in food. London: Elsevier Applied Science.

Elleuch, M., Besbes, S., Roiseux, O., Blecker, C., \& Attia, H. (2007). Quality characteristics of sesame seeds and by-products. Food Chemistry, 103(2), 641-650. http://dx.doi.org/10.1016/j.foodchem.2006.09.008.

Escamilla-Silva, E. M., Guzmán-Maldonado, H. S., Cano-Medina, A., \& González-Alatorre, G. (2003). Simplified process for the production of sesame protein concentrate. Differential scanning calorimetry and nutritional, physicochemical and functional properties. Journal of the Science of Food and Agriculture, 83(9), 972-979. http://dx.doi. org/10.1002/jsfa.1434.

Fennema, O. R. (2000). Química de los alimentos (pp. 384-505). Mexico: Acribia.

Franco, J. M., Raymundo, A., Sousa, I., \& Gallegos, C. (1998). Influence of processing variables on the rheological and textural properties of lupin protein-stabilized emulsions. Journal of Agricultural and Food Chemistry, 46(8), 3109-3115. http://dx.doi.org/10.1021/jf980284v.

Guerrero, A., Partal, P., \& Gallegos, C. (1998). Linear viscoelastic properties of sucrose ester-stabilised oil-in-water emulsions. Journal of Rheology (New York, N.Y.), 42(6), 1375-1388. http://dx.doi. org/10.1122/1.550965.

Gonglun, C., \& Tao, D. (2004). An experimental study of stability of oil-water emulsion. Fuel Processing Technology, 86, 499-508.

Khalid, E. K., Babiker, E. E., \& EL Tinay, A. H. (2003). Solubility and functional properties of sesame seed proteins as influenced by $\mathrm{pH}$ and/or salt concentration. Food Chemistry, 82(3), 361-366. http:// dx.doi.org/10.1016/S0308-8146(02)00555-1.

Lupi, F. R., Gabriele, D., De Cindio, B., Sánchez, M. C., \& Gallegos, C. (2011). A rheological analysis of structured water-in-olive oil emulsions. Journal of Food Engineering, 107(3-4), 296-303. http:// dx.doi.org/10.1016/j.jfoodeng.2011.07.013.

Macosko, C. W. (1994). Rheology: principles, measurements and applications (p. 92). Weinheim: VCH Publisher.

Mcclements, D. J. (1999). Food emulsion (pp. 11-24). New York: C Press.

Mcclements, D. J. (2004). Protein-stabilized emulsions. Current Opinion in Colloid \& Interface Science, 9(5), 305-313. http://dx.doi. org/10.1016/j.cocis.2004.09.003.

Melik, D. H., \& Fogler, H. S. (1998). Fundamentals of colloidal stability in quiscent media. In R. Beccher (Ed.), Encyclopaedia of emulsion technology, (Vol. III, Chap. 1, pp. 3-78). New York: Marcel Dekker.

Norde, W. (2003). Colloids and interfaces in life sciences. New York: Marcel Dekker.

Onsaard, E. (2012). Sesame proteins. International Food Research Journal, 19(4),1287-1295.

Onsaard, E., Pomsamud, P., \& Audtum, P. (2010). Functional properties of sesame protein concentrates from sesame meal. Asian Journal of Food and Agro-Industry, 3(4), 420-431.

Partal, P., Guerrero, A., Berjano, M., \& Gallegos, C. (1997). Influence of concentration and temperature on the flow behaviour of oil-in-water 
emulsions stabilised by sucrose palmitate. Journal of the American Chemical Society, 74(10), 1203-1212.

Quintana, S. E., Franco, J. M., \& Garcia-Zapateiro, L. A. (2015). Physicochemical and bromatological characteristics of arenca (Triportheus magdalenae), and rheological properties of oil-in-water emulsions containing isolated protein. Ciência e Agrotecnologia, 39(6), 634-641. http://dx.doi.org/10.1590/S1413-70542015000600010.

Robins, M. (2000). Emulsions: creaming phenomena. Current Opinion in Colloid \& Interface Science, 5(5-6), 265-272. http://dx.doi.org/10.1016/ S1359-0294(00)00065-0.

Saydut, A., Duz, M., Kaya, C., Kafadar, A., \& Hamamci, C. (2008). Transesterified sesame (Sesamum indicum L.) seed oil as a biodiesel fuel. Bioresource Technology, 99(14), 6656-6660. http://dx.doi. org/10.1016/j.biortech.2007.11.063. PMid:18178427.

Tunde-Akintunde, T. Y., Oke, M. O., \& Akintunde, B. O. (2012). Sesame seed. In U. G. Akpan (Ed.), Oilseeds (Chap. 5, pp. 81-98).
Rijeka: InTech. Retrieved from: http://www.intechopen.com/books/ oilseeds/sesame-seed.

Vojdani, F. (1996). Solubility. In M. G. M. Hall, Methods of testing protein functionality (pp. 11-60). London: Blackie Academic \& Professional.

Wagner, J. R., \& Gueguen, J. (1999). Surface functional properties of native, acid-treated, and reduced soy glicinin, 2. Emulsifying properties. Journal of the Science of Food and Agriculture, 47(6), 2181-2187. http://dx.doi.org/10.1021/jf9809784. PMid:10794606.

Walstra, P. (1996a). Emulsion stability. In P. Beccher (Ed.), Encyclopaedia of emulsion technology (Vol. 4, Chap. 1, pp. 1-62). New York: Marcel Decker.

Walstra, P. (1996b). Disperse systems: basic considerations. In O. R. Fennema (Ed.), Food Chemistry (3rd ed, Chap. 3, pp. 96-151). New York: Marcel Decker.

Walstra, P. (2003). Physical chemistry of foods. New York: Marcel Decker. 